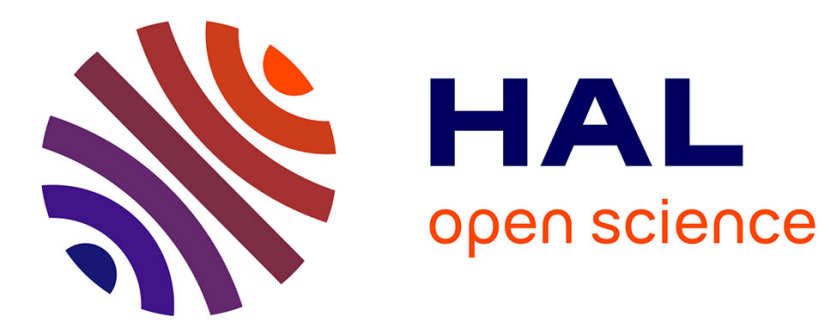

\title{
Directed overexpression of insulin in Leydig cells causes a progressive loss of germ cells
}

Katayoon Shirneshan, Stefan Binder, Detlef Böhm, Stephan Wolf, Ulrich Sancken, Andreas Meinhardt, Michael Schmid, Wolfgang Engel, Ibrahim M. Adham

\section{To cite this version:}

Katayoon Shirneshan, Stefan Binder, Detlef Böhm, Stephan Wolf, Ulrich Sancken, et al.. Directed overexpression of insulin in Leydig cells causes a progressive loss of germ cells. Molecular and Cellular Endocrinology, 2008, 295 (1-2), pp.79. 10.1016/j.mce.2008.07.007 . hal-00532051

\section{HAL Id: hal-00532051 https://hal.science/hal-00532051}

Submitted on 4 Nov 2010

HAL is a multi-disciplinary open access archive for the deposit and dissemination of scientific research documents, whether they are published or not. The documents may come from teaching and research institutions in France or abroad, or from public or private research centers.
L'archive ouverte pluridisciplinaire HAL, est destinée au dépôt et à la diffusion de documents scientifiques de niveau recherche, publiés ou non, émanant des établissements d'enseignement et de recherche français ou étrangers, des laboratoires publics ou privés. 


\section{Accepted Manuscript}

Title: Directed overexpression of insulin in Leydig cells causes a progressive loss of germ cells

Authors: Katayoon Shirneshan, Stefan Binder, Detlef Böhm, Stephan Wolf, Ulrich Sancken, Andreas Meinhardt, Michael Schmid, Wolfgang Engel, Ibrahim M. Adham

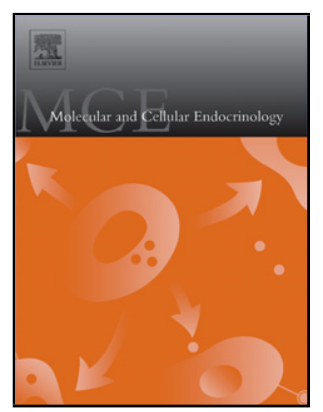

PII: S0303-7207(08)00291-8

DOI: doi:10.1016/j.mce.2008.07.007

Reference: MCE 6920

To appear in: Molecular and Cellular Endocrinology

Received date: 27-3-2008

Revised date: $3-7-2008$

Accepted date: $5-7-2008$

Please cite this article as: Shirneshan, K., Binder, S., Böhm, D., Wolf, S., Sancken, U., Meinhardt, A., Schmid, M., Engel, W., Adham, I.M., Directed overexpression of insulin in Leydig cells causes a progressive loss of germ cells, Molecular and Cellular Endocrinology (2007), doi:10.1016/j.mce.2008.07.007

This is a PDF file of an unedited manuscript that has been accepted for publication. As a service to our customers we are providing this early version of the manuscript. The manuscript will undergo copyediting, typesetting, and review of the resulting proof before it is published in its final form. Please note that during the production process errors may be discovered which could affect the content, and all legal disclaimers that apply to the journal pertain. 
Directed overexpression of insulin in Leydig cells causes a progressive loss of germ cells

\author{
Katayoon Shirneshan ${ }^{\mathrm{a}}$, Stefan Binder ${ }^{\mathrm{a}}$, Detlef Böhm ${ }^{\mathrm{a}}$, Stephan Wolf ${ }^{\mathrm{a}}$, Ulrich Sancken ${ }^{\mathrm{a}}$, \\ Andreas Meinhardt ${ }^{\mathrm{b}}$, Michael Schmid ${ }^{\mathrm{c}}$, Wolfgang Engel ${ }^{\mathrm{a}}$, Ibrahim M. Adham ${ }^{\mathrm{a}}$ * \\ aInstitute of Human Genetics, University of Göttingen, D-37073 Göttingen, Germany; \\ ${ }^{\mathrm{b}}$ Department of Anatomy and Cell Biology, University of Giessen, D-35385 Giessen, \\ Germany; 'Institute of Human Genetics, University of Würzburg, D-97074 Würzburg, \\ Germany.
}

Keywords: Ins13; Insulin; Transgenic mice

Short Title: Insulin overexpression impairs spermatogenesis

Corresponding author at: Institute of Human Genetics, University of Göttingen, HeinrichDüker-Weg 12, D-37073 Göttingen, Germany. Tel.: +49 551 397522; fax: +49 551399303.

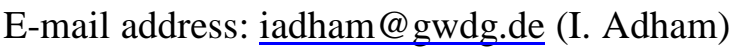




\section{Abstract}

The primary goal of this study was to determine the 5'region of the Insl3 gene that specifically targets the expression of human insulin to Leydig cells, and to explore whether the testicular proinsulin is efficiently processed to insulin that is able to rescue the diabetes in different mouse models of diabetes. We show here that the sequence between nucleotides 690 to +4 of mouse Insl3 promoter is sufficient to direct the Leydig cell-specific expression of the human insulin transgene (Insl3-hIns). We also found that the $3^{\prime}$ untranslated region (3'UTR) of Insl3 was effective in enhancing transgene expression of the insulin in vivo. Expression analysis revealed that the temporal expression pattern of the hIns transgene in Leydig cells of transgenic testes is roughly the same as that of the endogenous Insl3. Despite the Leydig cells translate human proinsulin and secrete a significant level of free C-peptide into the serum, the Leydig cell-derived insulin is not able to overcome the diabetes in different mouse models of diabetes, suggesting a lack of glucose sensing mechanisms in the Leydig cells. A consequence of overexpression of the human proinsulin in Leydig cells was the decrease of fertility of transgenic males at older ages. Germ cells in transgenic males were able to initiate and complete spermatogenesis. However, there was a progressive and agedependent degeneration of the germ cells that lead to male infertility with increasing age. 


\section{Introduction}

Diabetes mellitus is a group of diseases characterised by an absolute or relative insulin deficiency and by poor glucose control (hyperglycemia) in the blood. In type I diabetes, also known as insulin-dependent diabetes mellitus (IDDM) or juvenile-onset diabetes mellitus, there is an absolute lack of insulin due to the progressive loss of pancreatic $\beta$-cells in the islets of Langerhans. Despite intensive research efforts, daily insulin injection remains the only therapy. This unsatisfactory treatment strongly affects the life style of the patients and cannot achieve the same degree of glycemic control as provided by endogenous insulin produced from the pancreatic $\beta$-cells. Therefore, transplantation of insulin-producing tissues and gene therapy are potential therapeutically strategies to overcome type I diabetes. Large-scale application of islet cell implantations to type I diabetic patients is hindered by limited availability of insulin-producing tissues and the subsequent need for life-long immunosuppressants (Remuzzi et al., 1994). An alternative approach is the ectopic expression of insulin in other tissues using gene therapy. The goal is to restore and to control insulin production in another tissue, thereby reducing the elevated blood glucose levels to a normal range without causing hypoglycemia. For successful therapy, at least three crucial issues must be adequately addressed. The ectopic tissues expressing engineered insulin must have constitutive and regulated secretory pathways and express proprotein convertases PC2 and PC1/3 that are required for proinsulin processing (Steiner, 1998). These cells must have glucose sensing mechanisms for adequate regulation of insulin secretion according to blood glucose levels.

Several approaches, which have been taken in mind these crucial issues, have addressed the feasibility of in vivo gene therapy for the delivery of insulin to diabetic patients. Target tissues tested include liver, muscle, pituitary, exocrine pancreas and intestinal K-cells (Valera et al., 1994; Kolodka et al., 1995; Lipes et al., 1996; Goldfine et al., 1997; Bartlett et al., 
1997; Abai et al., 1999; Bochan et al., 1999; Cheung et al., 2000; Lu et al., 2005). The results are rather disappointing.

INSL3, a member of the insulin superfamily, is synthesized as preprotein in pre- and postnatal Leydig cells and play an essential role in growth of gubernaculums ligament during transabdominal descent of the testis (Zimmermann et al., 1997; 1999; Balvers et al., 1998; Nef and Parada, 1999; Adham et al., 2002; Koskimies et al., 2003). Although the structure of circulating INSL3 is only known in bovine (Büllesbach and Schwabe, 2002), the presence of certain conserved amino acids of the $\mathrm{A}$ and $\mathrm{B}$ chain at the $\mathrm{N}$ and $\mathrm{C}$ termini of the pro-INSL3 suggests that the mode of in vivo processing of pro-INSL3 and resulting structure of INSL3 is similar to that of insulin and relaxin (Adham et al., 1993; Hombach-Klonisch et al., 2004). It is known that the processing of the proinsulin occurs in the trans-Golgi by a regulated secretory pathway (Kelly, 1985; Rhodes and Halban, 1987). Similar to islet $\beta$ cells, several endocrine cells such as intermediate lobe pituitary cells, and gastrointestinal G and $\mathrm{K}$ cells efficiently process proinsulin to mature, biologically active insulin via a regulated pathway of protein secretion (Lipes et al. 1996, Cheung et al., 2000; Lu et al., 2005), whereas in hepatocytes, which have only a constitutive pathway of protein secretion, proinsulin processing to insulin is extremely inefficient (Valera et al., 1994; Kolodka et al., 1995).

To assess the efficiency of the endocrine Leydig cells in processing the proinsulin to the biological active insulin and to determine the ability of the testicular insulin to overcome the diabetes in mice, we overexpressed insulin in the Leydig cells during pre- and postnatal development. The rational for this study was underpinned by our previous study showing that ectopic expression of Insl3 in $\beta$-cells rescue the cryptorchidism in Insl3-null males. These results reveal that the $\beta$-cells efficiently processed the Insl3 gene product to the functional hormone. To achieve our goal, the insulin was targeted using the upstream regulated sequence of murine Insl3 gene, and transgenic mice were generated. To determine whether the 
testicular insulin would rescue diabetes observed in the Pax-4 deficient mice, we introduced the transgenic allele into the $\operatorname{Pax}-4^{-/-}$mice.

\section{Materials and Methods}

\subsection{Generation of transgenic mice}

The 0.7-kb HindIII/XbaI fragment containing the 5'flanking region of mouse Insl3 was isolated from the p690-CAT plasmid (Zimmermann et al., 1998) and subclond into pBluescript IIKS+ (Stratagen) to produce pInsl3. To generate the Insl3-hIns/1 construct, a 1.7-kb genomic fragment containing exons 1-3 of human insulin gene (hIns) was amplified using the primers Hins2F: 5’- GCC GCT CTA GAC CTG AGC CCT CCA GGA CAG -3’and Hins2R: 5'- GCC GCG CGG CCG CGG GAG GGG CTC ACA ACA GTG C -3’' The 1.7-kb amplified fragment with an artificial XbaI site at $5^{\prime}$-end and a NotI site at $3^{\prime}$-end was inserted into the XbaI/NotI-digested pInsl3 to create Insl3-hIns/1 construct. A 1.3-kb XbaI/NotI fragment containing the genomic sequence of hIns without the $3^{\prime}$ untranslated region was amplified using the primers Hins2F and Hins11R: 5- GCC GCG CGG CCG CCC TGC AGG CTG CGT CTA GTT $-3^{\prime}$ and subcloned into pInsl3 to create the pInsl3-hIns $\Delta 3^{\prime}$. Finally, a 250-bp NotI/SstII genomic fragment containing the 3'untranslated region of mouse Insl3 was amplified using the primers Minsl1F: 5'- GCC GCG CGG CCG CTG AAG GAG CAC AGG GCT CAG G -3’and Minsl1R: 5’- GCC GCC CGC GGC GGT CTG GTC CGT GTG TGA CC -3', and inserted into pInsl3-INS to generate the construct Insl3-INS/2. The nucleotide sequence of the amplified fragments was confirmed by DNA sequencing.

The fragments containing mouse Insl3 promoter-human insulin hybrid gene (Insl3-hIns) were separated from the constructs Insl3-hIns/1 and Insl3-hIns/2 by HindIII/NotI, purified by agarose gel electrophoresis, and microinjected into fertilized FVB/N eggs to generate transgenic mice Insl3-INS/1 and Insl3-INS/2.

Mice were genotyped for the presence of the transgene by PCR designed to amplify a region spanning the junction between the mouse Insl3 promoter and the human insulin gene. 
For genotyping the transgenic Insl3-INS/1 animals, PCR assays with primers Lyk2, 5'GCCGCAAGCTTCCGCACCTGGGAGAGG-3’and HinsR3, 5’GGCAGAAGGACAGTGATCTGG-3’ were performed. Thermal cycling was carried out for 35 cycles, denaturation at $94^{\circ} \mathrm{C}$ for $30 \mathrm{sec}$, annealing at $54^{\circ} \mathrm{C}$ for $30 \mathrm{sec}$, and extension at $72^{\circ} \mathrm{C}$ for $45 \mathrm{sec}$. Primers Lyk2 and HinsR5: 5'-AAAAAAGTGCACCTGACCCCCTGC$3^{\prime}$ were used for genotyping the transgenic Insl3-INS/2 mice. Copy number and number of integration sites of transgenic founders were determined by a quantitative real-time PCR approach as described previously (Boehm et al., 2004).

Transgenic lines were maintained on the genetic background of FVB/N. All animal experiments were carried out using protocols approved by the Medical Faculty of University of Göttingen and Research Advisory Committee.

\subsection{Generation of Insl3-hIns: Pax4 ${ }^{-/}$double mutant mice}

Mating Insl3-hIns hemizygous males with $\mathrm{Pax}^{+/-}$females (Sosa-Pineda et al. 1997) produced Insl3-hIns: $\mathrm{Pax}^{+/}$mice, which were then crossed to produce mice homozygous for the disrupted Pax4 gene and hemizygous for the Insl3-hIns transgene (Insl3-hIns: Pax4 ${ }^{-/}$). The following primers were used to discriminate between wild-type and mutant Pax4 alleles. Primers Pax 4F: 5’ ATG GCT GTG TGA GCA AGA TCC -3’and primer Pax 4R: 5'- TCC AGC TTC CCT TAA CTC CAG -3’ were designed to amplify a 250-bp fragment of wildtype allele. The primer LacZ-F. 5'- TTG GCG TAA GTG AAG CGA C -3' was used with the primer LacZ- R: 5’- AGC GGC TGA TGT TGA ACT G -3’ to amplify a 500-bp fragment of mutant Pax4 allele.

\subsection{RNA analysis}

Different tissues were dissected out from 3-month-old wild-type and transgenic mice or from testes of 1-, 3-, 5-, 6-, 8-, 10-, 15-, 20-, and 25-d-old males. Total RNA was prepared using total RNA Isolation Reagent (Biomol, Hamburg), electrophoresed on 1.2\% agarose gels 
containing 2.2 M formaldehyde and transferred onto a nylon membrane. The membrane was

hybridized with ${ }^{32} \mathrm{P}$-labelled human insulin cDNA fragment. RNA integrity was checked by rehybridization of blots with a cDNA probe for human elongation factor-2.

RT-PCR assays were performed using $2 \mu \mathrm{g}$ of total RNA and a One Step RT-PCR kit (QIAGEN). Primers to amplify the PC1 cDNA fragment were 5'- TCA ACC AGA GCA CAT GAA GC -3' and 5'- GCA GCA GCC TGT CAT CTC TA -3', and those to amplify the $P C 2$ transcript were 5'- ATG GAG GGC GGT TGT GGA TC -3' and 5'- CAG GTA CCA TTG CTT TGT AAA GAG A -3'.

\subsection{Immunohistochemistry}

Testis and pancreas from wild-type and Insl3-hIns transgenic mice were fixed in Bouin's fixative and transferred to $70 \%$ ethanol before paraffin embedding. Sections $(5 \mu \mathrm{m})$ were cut from paraffin blocks with a rotary microtome and mounted on SuperFrost Plus glass slides (Fisher Scientific, Nepean, Canada). Sections were deparaffinized in xylene, rehydrated in a descending alcohol. Thereafter, tissue sections were preincubated for $1 \mathrm{~h}$ with $10 \%$ normal horse serum in $2 \%$ Tween/PBS and incubated overnight at $4{ }^{\circ} \mathrm{C}$ with 1:500 mouse monoclonal anti-insulin antibody (Sigma, St. Luis, USA), washed in PBS, and then incubated with CY3conjugated goat anti-mouse antibody (1:500) (Sigma) for $30 \mathrm{~min}$ at room temperature. Slides were then washed in PBS, stained with DAPI (Vector), and examined with a BX60 microscope (Olympus, Hamburg, Germany) with fluorescence equipment and an analysis software program (Soft Imaging System, Münster, Germany).

\subsection{Measurement of proinsulin and C-peptide level in protein extracts and serum}

To determine pancreatic and testicular proinsulin content, whole pancreas and testis was removed from the mice, weighted, and homogenized in $20 \mathrm{vol}$ of cold acidic ethanol (75\% ethanol, $1.5 \%$ concentrated $\mathrm{HCl}$ ) followed by $48 \mathrm{~h}$ of agitation at $4^{\circ} \mathrm{C}$. Thereafter, insulin was quantified in the supernatants of the samples by time-resolved fluoroimmunoasssay. Insulin 
concentrations in testis and pancreas extracts were determined by Auto DELFIA Insulin Assay following the supplier's protocol (Perkin-Elmer Life Sciences, Wallac Oy, Finland). Serum C-peptide was determined by radioimmunoassay (RIA) (Linco Research, St. Charles, USA) following the manufacturer's instructions, using specific ${ }^{125}$ I-labelled human C-peptide as tracer and a human C-peptide antibody. Antibody was $100 \%$ crossreactive with human Cpeptide and $<4 \%$ crossreactive with human proinsulin (Sensitivity of $0.1 \mathrm{ng} / \mathrm{ml}$ ).

\subsection{Generation of diabetic mice}

To induce insulin-dependent diabetes, 2-month-old male mice were injected intraperitoneally with streptozotocin (STZ) (Sigma, Munich, Germany) (33.3 mg/kg body weight), dissolved in $50 \mathrm{mmol} / \mathrm{l}$ citrate buffer ( $\mathrm{pH} 4.5$ ) for 5 consecutive days. Blood glucose was determined four times a week in blood obtained from the tail vein using a HeamoglucoTest glucometer (Roche Molecular Biochemicals, Mannheim, Germany). Mice were considered diabetic after two consecutive blood glucose values of more than $250 \mathrm{mg} / \mathrm{dl}$.

For glucose tolerance tests, STZ-treated transgenic and non-treated wild-type mice were fasted overnight with free access to water and thereafter injected intraperitoneally with glucose (1 mg/kg body weight). Blood samples were obtained from the tail vein before the glucose injection and at 20,40, and 60 min after injection, and the glucose concentration was measured as indicated above.

\subsection{Fertility test and sperm parameters}

To investigate the fertility of the transgenic males on a FVB/N background, 3-month-old male mice were mated each with two wild-type FVB/N females. Females were checked for the presence of vaginal plug and/or pregnancy. Pregnant females were removed to holding cages to give birth. Litter size sired by each group of males was determined after 4-, 8- and 12-months of breeding. 
The epididymides from transgenic male mice were collected and dissected in IVF medium. Sperm number in the cauda epididymis was determined using a Neubauer counting cell chamber. Motility was analysed by a CEROS computer-assisted semen analysis system (version 10; Hamilton Thorne Research, Beverly, Mass).

\subsection{Statistical analysis}

All results are presented as the means \pm SD (SEM). The significance of differences was assessed using the Student's $t$ test. Differences were considered significant at $p<0.05$.

\section{Results}

\subsection{Generation of Insl3-hIns transgenic mice}

Analyses of the mouse Insl3 promoter in vitro predicted that the proximal region of Insl3 promoter might be sufficient for targeted expression of reporter gene in Leydig cells (Zimmermann et al., 1998; Koskimies et al., 2002). To determine the regulatory sequences of Insl3, which are required for Leydig cell-specific expression of reporter gene in vivo and for stability of transgenic RNA in Leydig cells, two transgenic constructs were designed using the $5^{\prime}$ flanking region of Insl3 (-690 to +4) fused to the human insulin gene (hIns). In the first construct (Insl3-hIns/1), the three exons of hIns including the 3'untranslated region were ligated downstream of 5 'regulatory sequence of Insl3. In the second construct (Insl3-hIns/2), the 3 untranslated sequence of hIns was replaced with that of mouse Insl3 (Fig. 1A). Both fusion constructs were microinjected into the pronuclei of fertilized FVB/N mouse eggs. Four and five transgenic founders were found to carry the Insl3-hIns/1 and the Insl3-hIns/2 fusion allele, respectively, as detected by PCR assay using specific primers (data not shown). Transgenic mice were maintained as hemizygotes and mated to wild-type FVB/N for further analyses. 


\subsection{Expression analysis of transgenic insulin in Leydig cells}

To determine whether the Insl3-INS transgenic alleles are transcriptional active, Northern blots containing total RNA extracted from testes of F1-animals of four transgenic Insl3-INS/1 and five transgenic Insl3-hIns/2 founders were hybridized with the hIns cDNA probe. As shown in figure 1B, the expression of Insl3-hIns/l transgenic allele was only detectable at low level in testis of line \#4. In contrast, high levels of hIns mRNA were found in testes of four Insl3-hIns/2 transgenic lines (Line \#5, \#7, \#8 and \#9). Using the sensitive RT-PCR assay, we were able to detect the hIns transcripts in testes of transgenic lines \#1, \#2 and \#3, but not in line \#6. Breeding of transgenic mice from line \#6 with wild-type females revealed that the transgenic allele in this line is only transmitted to male offspring indicating the integration of fusion construct in the Y-chromosome. Using real time PCR, we have estimated the number of copies and integration sites of transgenic allele in genome of transgenic lines \#4, \#5, \#7, \#8 and \#9. PCR analysis of founders and their progeny showed that the Insl3-hIns transgenic DNA was only inherited with constant copy numbers in lines \#4, \#5 and \#9 suggesting the presence of one integration site in genome of these lines (data not shown). Higher levels of the Insl3-hIns/2 expression in testes of transgenic lines \#5 and \#9 with 3 and 16 copies of transgenic allele, respectively, than that of Insl3-hIns/1 allele in transgenic line \#4 with 9 copies suggested that the 3 untranslated sequence of Insl3 enhances transgene expression in vivo. Due to single integration site of the transgene in genome and the robust transgenic expression level in testes of transgenic lines \#5 and \#9, these lines were used for further analyses. Transgenic mice of both lines were healthy and had a normal lifespan.

To determine the extent of transgene expression, we performed Northern blot analysis of various tissues from hemizygous offspring of line \#5 using a hIns cDNA probe. A transcript of the expected size $(0.7-\mathrm{kb})$ was observed in testis of transgene, but not in other tissues (Fig. 1C). 
The temporal regulation of the hIns-transgene expression was analyzed by Northern blot with testicular RNA from sequential time points of postnatal development. During the first three weeks of testis development, equal levels of the transgene transcript were observed. The Insl3 expression was also determined from the same blot using an Insl3 cDNA probe. After three weeks of postnatal testis development, the hIns mRNA level gradually increased, showing an expression pattern roughly similar to that of the endogenous Insl3 mRNA (Fig. 1D).

The distribution of hINS protein in the testis was determined by using monoclonal antibody to human insulin. In testis sections of transgenic mice, insulin immunoreactivity was detected in Leydig cells, confirming that human insulin protein production was specifically targeted to Leydig cells (Fig. 1E). Results of these expression experiments provide evidence that the sequence -690 to +4 of the 5 flanking region of Insl3 directs in vivo the transcription of reporter gene in Leydig cells but not in other tissues, indicating that the cis-acting elements of Leydig cell-specific expression reside within this region.

\subsection{Leydig cells translate and process proinsulin}

To determine the translation rate of the transgene, proinsulin content was measured in testes and pancreas of fasted wild-type and transgenic males (> 8-week-old) by a fluoroimmunoassay, which specifically recognizes the human and mouse form of proinsulin As shown in figure $2 \mathrm{~A}$, proinsulin levels in testicular extracts of transgenic mice $(10.75 \pm$ $0.99 \mu \mathrm{U} / \mathrm{mg}, n=13$ ) were not significantly different from that in pancreas of wild-type (11.6 $\pm 1.34 \mu \mathrm{U} / \mathrm{mg}, n=6)$ and transgenic pancreas $(12.23 \pm 1.08 \mu \mathrm{U} / \mathrm{mg}, n=13)$. Similar concentrations of proinsulin were found in transgenic and control pancreas. In contrast, only basal level of proinsulin was detected in wild-type testis (Fig. 2A). These results suggest that the human proinsulin produced by transgenic allele do not alter the expression of endogenous insulin production in the pancreas. 
To determine the testicular expression of prohormone convertases PC2 and PC1/3 that process the proinsulin to insulin, we performed RT-PCR analysis. This analysis revealed the expression of $\mathrm{PC} 1$ and $\mathrm{PC} 1 / 3$ in testicular Leydig cells (data not shown).

Whether testicular proinsulin is processed to insulin which is secreted into serum, free human C-peptide in serum of fasted wild-type and transgenic males was measured with Cpeptide-specific immunoassay that has no cross-reactivity with mouse insulin or human proinsulin. The levels of human C-peptide in samples collected from individual mice of transgenic line \#5 and \#9 was $0.51 \pm 0.45 \mathrm{ng} / \mathrm{ml}(n=11)$ and $0.43 \pm 0.41 \mathrm{ng} / \mathrm{ml}(n=11)$, respectively, whereas serum $\mathrm{C}$-peptide levels in wild-type males were below the detection limits of radioimmunoassay (Fig. 2B). However, the C-peptide levels in serum of both transgenic lines were lower than the normal level of C-peptide in human serum (0.5-4.0 $\mathrm{ng} / \mathrm{ml}$ ). The presence of human C-peptide in serum of transgenic males indicates that the Leydig cell-produced proinsulin is processed to insulin, and secreted into the serum. However, transgenic mice display normal blood glucose levels whether fed or fasted (Fig. 2C). The body weights of transgenic males at the age of 3- and 6-months were indistinguishable from those of their control littermates (Fig. 2D).

\subsection{Testicular insulin can not rescue the diabetic Pax-4 deficient mice}

We have then investigated the efficiency of Leydig cell-derived human insulin to rescue the diabetes in Pax4-deficient mice, in which the development of $\beta$ - and $\sigma$-cells of the pancreas is impaired (Sosa-Pineda et al., 1997). We have introduced the Insl3-hIns/2 allele into the genome of $\mathrm{Pax}^{-/-}$mice by breeding the line \# 5 with the $\mathrm{Pax}^{+/-}$mice and analyzed the glucose level and lifespan of the $\operatorname{Pax}^{-/}$: Insl3-hIns/2 double mutant mice in F2 generation. The resulting double-mutant progeny from heterozygous intercrosses were born as expected from Mendelian ratio, but died within 7 days after birth. Blood glucose levels of the double mutant neonates were not significantly different from those in Pax $4^{-/-}$littermates 
$(220.3 \pm 12.2$ versus $242 \pm 9.3, n=6$ in each group), but were significantly higher than that in wild-type littermates $(120.3 \pm 4.6, n=6)$. These results indicate that testicular INS was not able to overcome the diabetes resulting from the impaired development of pancreatic $\beta$-cells in $\operatorname{Pax}^{-1-}$ mice.

\subsection{Leydig cells lack the glucose sensing mechanism}

The insufficiency of testicular insulin to rescue the $\operatorname{Pax}^{-/}$neonates from diabetes may be due to impairment of Leydig cells to secret high levels of human insulin in response to increase of blood glucose levels. Therefore, we examined whether insulin production from Leydig cells was able to maintain glucose tolerance in the transgenic animals. Streptozotocin (STZ), a $\beta$-cell toxin, was administered to transgenic and wild-type mice. In both transgenic and wild-type animals, STZ-treatment resulted in hyperglycemia (Fig. 2E) indicating the development of diabetes. To ensure that the STZ treatment did not destroy the Leydig cells in these experimental animals, expression of the Insl3 was determined in testes of controls and STZ-treated transgenic animals. Results of the RNA analysis revealed that the expression of Insl3 is not affected from STZ-treatment, indicating that the Leydig cells escape the STZ treatment (data not shown). Fasted STZ-treated transgenic and untreated wild-type animals were then intraperitoneally injected with glucose. Blood glucose levels were dramatically decreased in control animals at 40 and 60 min after injection. In contrast, the human insulin produced from Leydig cells of transgenic mice was not sufficient to restore normal glucose tolerance (Fig. 2F).

\subsection{Progressive loss of germ cells in the Insl3-hIns-transgenic testis}

To identify and establish homozygous transgenic mice, 10 transgenic males and females from F2 generation were crossed with wild-type mice. Genotyping of offspring from these breeding revealed that all homozygous transgenic females of line \#5 and \#9 are fertile. In contrast, all fertile males of both transgenic lines are hemizygous for transgene. Using real 
time PCR, we have estimated the copy number of transgenic allele in the genomes of 4 infertile males and their fertile littermates. PCR analysis revealed that infertile males from each line have double copy numbers of transgenic allele as compared to hemizygous males suggesting that increased expression of transgenic allele impairs the fertility of homozygous animals.

Breeding of hemizygous transgenic males with wild-type mice revealed that the fertility of transgenic males at 4-months-old did not significantly differ from that of controls. However, the litter size produced by transgenic males declined with advancing age (Table 1). We noticed a large variability in the age on onset of infertility among transgenic mice. Some mice were initially fertile but developed infertility later on.

To investigate the underlying cause of reproductive defects in transgenic males, sperm parameters were analyzed in great detail. As shown in Table 1, significant reduction in the mean number of spermatozoa and the proportion of motile and progressively motile sperm collected from the cauda epididymides of 8 - and 12-months-old transgenic mice $(\mathrm{p}<0.001)$.

Next, we investigated potential pathologic alterations in testes of 4-, 8- and 12-months-old transgenic mice. At 4-months-old, there were no gross morphological differences between wild-type and transgenic seminiferous tubules (Fig. 3A, B). Transgenic testes from 8-monthold revealed a mixed atrophy type of damage showing seminiferous tubules with apparently normal spermatogenesis, tubules with focally degenerated germ cells or tubules with almost complete loss of spermatogenic cells. Often damaged tubules contained vacuoles. Overall, a large variability in the degree of testicular degeneration was observed within one tubule crosssection, amongst neighbouring tubules and amongst testes of different transgenic mice at this age (Fig. 3C). During the next months, the phenotype becomes more pronounced. In testes of 12-months-old transgenic mice, about $85 \%$ of all seminiferous tubules displayed severe impairment of spermatogenesis with severe vacuolization of most affected tubules (Fig. 3D). To determine whether the germ cell loss in transgenic testis resulted from increased germ cell 
apoptosis, we used TUNEL assay to detect apoptotic cells in 4- and 8-months-old wild-type and transgenic testis. In transgenic testis, we observed only a few apoptotic cells, and the number and position of these cells were similar to those of wild-type, indicating that the degeneration of spermatogenic cells is not due to increased germ cell apoptosis (data not shown). Therefore, the observed phenotype may be caused by impairment of early germ cell proliferation or differentiation rather than by a specific arrest during spermatogenesis.

\section{Discussion}

Previous cell culture experiments have shown that the sequence from -690 to +4 of Insl3 gene was able to direct expression of reporter constructs in Leydig cell lines (Zimmermann et al., 1998; Koskimies et al., 2002). In order to determine whether this part of the promoter is also sufficient in vivo to direct tissue- and cell-specific expression, transgenic mice were generated. The transgene Insl3-hIns/1 contains the sequence between -690 to +4 of Insl3 promoter cloned upstream of the human insulin gene as reporter. The data show that this transgenic allele is expressed at low levels in all four generated lines. The results of many studies showed that the $3^{\prime}$-untranslated region of a gene influences the stability of its mRNA (Ross, 1995; Kakoki et al., 2004). Based on these results, we replaced the 3'untranslated region of human insulin gene with that of mouse Insl3 in the second construct Insl3-hIns/2. Four of five Ins13-hIns/2 transgenic lines showed significantly higher transgene expression than those in testes of Insl3-hIns/1 transgenic lines, despite the presence of comparable copy number of both transgenic alleles. These results suggest that the $3^{\prime}$-untranslated region of Insl3 contains elements, which are responsible for stability of transgenic transcripts in Leydig cells. Just as endogenous Insl3 expression, expression of transgenic Insl3-hIns/2 allele is restricted to Leydig cells and expression level is constant through the first three weeks of postnatal testis development and increases gradually thereafter. Thus, the promoter and the 
3'untranslated region of Insl3, which we have characterized here, will provide a useful tool to direct the specific expression of genes to Leydig cells in vivo.

We next explored whether the testicular proinsulin is efficiency processed to insulin which is able to rescue the diabetes in Pax $-4^{-/-}$mice. The in vivo data revealed that proinsulin content of transgenic testes was not significantly different from that of wild-type pancreas. The presence of a significant amount of immunoreactive free human C-peptide in serum of transgenic mice suggests that the ectopically produced insulin is secreted in the circulation. However, the testis-derived insulin is not able to reverse diabetic symptoms in Pax4-deficient mice. Endogenous insulin expression and secretion in pancreatic $\beta$ - cells is regulated by glucose, so that insulin will be produced and released in response to rise in blood glucose levels and is suppressed as blood glucose concentration decline. Results of glucose tolerance experiments revealed that a major limitation of this current gene delivery system is that the insulin secretion in the Leydig cells is not glucose regulated. A number of studies has engineered a variety of cells and tissues to produce insulin in transgenic mice. Lack of the glucose sensing mechanisms in target tissues, including liver, pituitary, muscle and exocrine pancreas, limit the clinical application of these approaches (Kolodka et al., 1995; Lipes et al., 1196; Goldfine et al., 1997; Bartlett et al., 1997; Abai et al., 1999; Valera et al., 1994; Bochan et al., 1999). In contrast, transgenic mice producing human proinsulin under the control of the K-cell specific GIP promoter have been shown to produce mature bioactive insulin in a glucose concentration-dependent manner (Cheung et al., 2000).

Insulin signalling is important for promoting and regulating of growth, differentiation, and metabolism. Disruption of components of the insulin-signaling pathway can result in infertility (Rane et al., 2000; Brüning et al., 2000). Reduced secretion of LH and FSH in diabetic men and in conditional knockout mice, which lack the insulin receptor (IR) in brain, revealed that insulin play a central role in regulation of hypothalamic pituitary testicular axis (Brüning et al., 2000; Baccetti et al., 2002). Impaired spermatogenesis of diabetic men was 
similar to those in IR-conditional knockout mice and characterized by increased germ cell depletion and Sertoli cell vacuolization. A notable phenotype in Insl3-hIns transgenic males is a progressive loss of germ cells. Normal glucose level in blood of transgenic males leads to exclude the idea that the disrupted spermatogenesis in aged mice is a result of diabetes. Therefore, there are two explanations for impaired fertility of aged mice. The ectopic expression of transgenic insulin gene in Leydig cells is not regulated by glucose level as it is the case for endogenous gene in $\beta$-cells. The overexpression may lead to overload of Leydig cells with proinsulin and induce endoplasmic reticulum (ER) stress. Such chronic ER stress caused by excessive demand of insulin in type II diabetes is responsible for $\beta$-cell exhaustion and decrease its secretory capacity (Oyadomari et al., 2002). Therefore, we suggest that the overload of Leydig cells with proinsulin may be deleterious for Leydig cell function. Dysregulation of stroidogenesis in transgenic males could be perturbed and that could explain the disruption observed on spermatogenesis yield and sperm motility. Alternatively, the Leydig cell-producing insulin has autocrine effects that negatively influence germ and Sertoli cell survival.

\section{Acknowledgments}

We would like to thank S. Schmidt, H. Riedesel for assistance with the generation and breeding of transgenic mice. We are grateful to Dr. P. Gruss at the Max-Planck-Institute of Göttingen for providing us with the $\operatorname{Pax}-4^{--}$mice. We also thank C. Müller for his help with particular experiments. 


\section{References}

Abai, A.M., Hobart, P.M., Barnhart, K.M., 1999. Insulin delivery with plasmid DNA. Hum. Gene Ther. 10, 2637-2649.

Adham, I.M., Burkhardt, E., Benahmed, M., Engel, W., 1993. Cloning of a cDNA for a novel insulin-like hormone of the testicular Leydig cells. J. Biol. Chem. 268, 26668-26672.

Adham, I.M., Steding, G., Thamm, T., Bullesbach, E.E., Schwabe, C., Paprotta, I., Engel, W., 2002. The overexpression of the insl3 in female mice causes descent of the ovaries. Mol. Endocrinol. 16, 244-252.

Baccetti, B., La Marca, A., Piomboni, P., Capitani, S., Bruni, E., Petraglia, F., De Leo, V., 2002. Insulin-dependent diabetes in men is associated with hypothalamo-pituitary derangement and with impairment in semen quality. Hum. Reprod. 17, 2673-2677.

Balvers, M., Spiess, A.N., Domagalski, R., Hunt, N., Kilic, E., Mukhopadhyay, A.K., Hanks, E., Charlton, H.M., Ivell, R., 1998. Relaxin-like factor expression as a marker of differentiation in the mouse testis and ovary. Endocrinology 139, 2960-2970.

Bartlett, R.J., Secore, S.L., Denis, M., Fernandez, L., Tzakis, A., Alejandro, R., Ricordi, C., 1997. Toward the biologic release of human insulin from skeletal muscle. Transplant Proc. 29, 2199-2200.

Bochan, M.R., Shah, R., Sidner, R.A., Jindal, R.M., 1999. Reversal of diabetes in the rat by injection of hematopoietic stem cells infected with recombinant adeno-associated virus containing the preproinsulin II gene. Transplant Proc. 31, 690-691.

Boehm, D., Herold, S., Kuechler, A., Liehr, T., Laccone, F., 2004. Rapid detection of subtelomeric deletion/duplication by novel real-time quantitative PCR using SYBR-green dye. Hum. Mutat. 23, 368-378. 
Brüning, J.C., Gautam, D., Burks, D.J., Gillette, J. Schubert, M., Orban, P.C., Klein, R., Krone, $\mathrm{W}_{.}$, Müller-Wieland, D., Kahn. C.R., 2000. Role of brain insulin receptor in control of body weight and reproduction. Science 289, 2122-2125.

Büllesbach, E.E., Schwabe, ${ }_{2}$., 2002. The primary structure and the disulfide links of the bovine relaxin-like factor (RLF). Biochemistry 41, 274-281.

Cheung, A.T., Dayanandan, B., Lewis, J.T., Korbutt, G.S., Rajotte, R.V., Bryer-Ash, M., Boylan, M.O., Wolfe, M.M., Kieffer, T.J., 2000. Glucose-dependent insulin release from genetically engineered K cells. Science 290, 1959-1962.

Goldfine, I.D., German, M.S., Tseng, H.C., Wang, J., Bolaffi, J.L., Chen, J.W., Olson, D.C., Rothman, S.S., 1997. The endocrine secretion of human insulin and growth hormone by exocrine glands of the gastrointestinal tract. Nat. Biotechnol. 15, 1378-1382.

Hombach-Klonisch, S., Schön, J., Kehlen, A., Blottner, S., Klonisch, T., 2004. Seasonal expression of INSL3 and Lgr8/Ins13 receptor transcripts indicates variable differentiation of Leydig cells in the roe deer testis. Biol. Reprod. 71, 1079-1087.

Kakoki, M., Tsai, Y.S., Kim, H.S., Hatada, S., Ciavatta, D.J., Takahashi, N., Arnold, L.W., Maeda, N., Smithies, O., 2004. Altering the expression in mice of genes by modifying their 3' regions. Dev. Cell. 6, 597-606.

Kelly, R.B., 1985. Pathway of protein secretion in eukaryotes. Science 230, 25-32.

Kolodka, T.M., Finegold, M., Moss, L., Woo, S.L., 1995. Gene therapy for diabetes mellitus in rats by hepatic expression of insulin. Proc. Natl. Acad. Sci. U.S.A. 92, 3293-3297.

Koskimies, P., Levallet, J., Sipila, P., Huhtaniemi, I., Poutanen, M., 2002. Murine relaxin-like factor promoter: functional characterization and regulation by transcription factors steroidogenic factor 1 and DAX-1. Endocrinology 143, 909-919.

Koskimies, P., Suvanto, M., Nokkala, E., Huhtaniemi, I.T., McLuskey, A., Themmen, A.P., Poutanen, M., 2003. Female mice carrying a ubiquitin promoter-Insl3 transgene have 
descended ovaries and inguinal hernias but normal fertility. Mol. Cell. Endocrinol. 206,159-166.

Lipes, M.A., Cooper, E.M., Skelly, R., Rhodes, C.J., Boschetti, E., Weir, G.C., Davalli, A.M., 1996. Insulin-secreting non-islet cells are resistant to autoimmune destruction. Proc. Natl. Acad. Sci. U.S.A. 93, 8595-8600.

Lu, Y.-C., Sternini, C., Rozengurt, E., Zhukova, E., 2005. Release of transgenic human insulin from gastric $\mathrm{G}$ cells: a novel approach for the amelioration of diabetes. Endocrinology 146, 2610-2619.

Nef, S., Parada, L.F., 1999. Cryptorchidism in mice mutant for Insl3. Nat. Genet. 22, 295299.

Oyadomari, S., Koizumi, A., Takeda, K., Gotoh, T., Akira, S., Araki, E., Mori, M., 2002. Targeted disruption of the Chop gene delays endoplasmic reticulum stress-mediated diabetes. J. Clin. Invest. 109, 525-532.

Rane, S.G., Dubus, P., Mettus, R.V., Galbreath, E.J., Boden, G., Reddy, E.P., Barbacid, M., 1999. Loss of Cdk4 expression causes insulin-deficient diabetes and Cdk4 activation results in beta-islet cell hyperplasia. Nat. Genet. 22, 44-52.

Remuzzi, G., Ruggeneti, P., Mauer, S.M., 1994. Pancreas and kidney/pancreas transplants:experimental medicine or real improvement? Lancet 343, 27-31.

Rhodes, C.J., Halban, P.A., 1987. Newly synthesized proinsulin/insulin and stored insulin are released from pancreatic $\beta$-cells predominantly via a regulated, rather than a constitutive, pathway. J. Cell Biol. 105, 145-153.

Ross, J., 1995. mRNA stability in mammalian cells. Microbiol. Rev. 59, 423-450.

Sosa-Pineda, B., Chowdhury, K., Torres, M., Oliver, G., Gruss, P., 1997. The Pax4 gene is essential for differentiation of insulin-producing beta cells in the mammalian pancreas. Nature 386, 399-402.

Steiner, D.F., 1998. The proprotein convertases. Curr. Opin. Chem. Biol. 2, 31-39. 
Valera, A., Fillat, C., Costa, C., Sabater, J., Visa, J., Pujol, A., Bosch, F. 1994. Regulated expression of human insulin in the liver of transgenic mice corrects diabetic alterations. FASEB J. 8, 440-447.

Zimmermann, S., Schottler, P., Engel, W., Adham, I.M., 1997. Mouse Leydig insulin-like (Ley I-L) gene: structure and expression during testis and ovary development. Mol. Reprod. Dev. 47, 30-38.

Zimmermann, S., Schwarzler, A., Buth, S., Engel, W., Adham, I.M., 1998. Transcription of the Leydig insulin-like gene is mediated by steroidogenic factor-1. Mol. Endocrinol. 12, 706-713.

Zimmermann, S., Steding, G., Emmen, J.M., Brinkmann, A.O., Nayernia, K., Holstein, A.F., Engel, W., Adham, I.M., 1999. Targeted disruption of the Ins13 gene causes bilateral cryptorchidism. Mol. Endocrinol. 13, 681-691. 


\section{Figure legends}

Fig. 1. Generation and expression analysis of the Insl3-hIns transgenic alleles. A, Schematic representation of the pInsl3-hIns/1 and pInsl3-hIns/2 transgenic construct. The pInsl3-hIns/1 transgenic construct consists of the $0.7-\mathrm{kb}$ of the Insl3 promoter (solid box) and the entire human insulin gene (hIns). In the pInsl3-hIns/2, the SstI/NotI genomic fragment containing the $3^{\prime}$ untranslated region of the human insulin gene was replaced with that of the mouse Insl3 (square box). Numbered boxes indicate location of exons of the hIns; thin lines show intron sequence. Relevant restriction sites used for generation of the transgenic vectors are indicated. H, HindIII; N, NotI; S, SstI; X, XbaI. B, Expression of the Insl3-hIns/1 and Insl3-hIns/2 transgenic allele in adult testes of different transgenic (L) lines and wild-type mice (WT) was determined by Northern blot hybridization with the hIns cDNA. Integrity of the RNA samples was confirmed by rehybridization of the blot with the elongation factor-2 cDNA (EF-2). C, Hybridization of Northern blot with total RNA from different tissues of transgenic line \# 5 reveals that the expression of the Insl3-hIns/2 transgenic allele is restricted in the testis. D, Expression pattern of Insl3-hIns/2 transgenic allele during the postnatal development of testis was determined by hybridization of Northern blot with testicular RNA isolated from transgenic mice of line \# 5 at different postnatal days (P). Blot was subsequently hybridized with the hIns-, Insl3-and EF-2-cDNA probes. D, Immunohistochemistry on sections of wildtype (WT) and transgenic testis (Tg). Insulin is highly accumulated in the Leydig cells of Insl3-hIns transgenic mice.

Fig. 2. Proinsulin content in testis and pancreas, C-peptide level in serum and regulation of testicular insulin release. A, Insulin and proinsulin immunoreactivity in testis and pancreas. RIA analysis was performed in acid extracts of testis and pancreas obtained from fasted wildtype (WT) and transgenic mice (Tg). B, Level of human C-peptide in serum of fasted wild- 
type and transgenic mice of line \#5 and \#9. C, Tail vein blood glucose measured in ad libitum-fed or 16-hour-fasted wild-type and transgenic males at the age of 3 and 6 months (M). D, Body weight of male wild-type and transgenic mice is given at the age of 3 and 6 months (M). E, Hyperglycemia development in wild-type and transgenic mice after STZtreatment. Glucose level was determine at the indicated times after STZ-treatment. F, Intraperitoneal insulin tolerance test. Thirty days after STZ treatment, overnight-starved STZtreated transgenic and non-treated wild-type mice were interperitoneally injected with $1 \mathrm{mg} / \mathrm{kg}$ body weight glucose, and serum glucose was determined at the indicated time.

Fig. 3. Progressive depletion of germ cells in testes of Insl3-hIns transgenic mice with advancing age. H\&E stained testis sections of 4-month-old wild-type (A), 4- (B), 8- (C) and 12-month-old transgenic mice (D) show a progressive degeneration of germ cells in the seminiferous tubules. In testis of 4-month-old transgenic mice (B), there was no gross morphological difference between wild-type (A) and transgenic seminiferous tubules (B). Panels show testicular sections of 8- (C) and 12-month-old transgenic mice (D). A significant proportion of tubules in 8- and a large majority of tubules in 12-month-old transgenic mice showed impairment of spermatogenesis with formation of vacuoles, release of premature germ cells and focal as well as full degeneration of germ cells (*). Magnification, X10. 
Table 1

Fertility and sperm parameters of transgenic and wild-type mice during postnatal development

\begin{tabular}{lcccc}
\hline & & 4 -month & 8 -month & 12-month \\
\hline Litter size & Wild-type mice & $6.6 \pm 1.2(6)$ & $5.8 \pm 0.8(6)$ & $5.2 \pm 1.3(6)$ \\
& Transgenic mice & $4.8 \pm 0.8(8)$ & $2.8 \pm 1.0^{*}(8)$ & $1.5 \pm 0.7^{*}(6)$ \\
& Wild-type mice & $13.2 \pm 3.1(3)$ & $8.6 \pm 3.4(3)$ & $5.7 \pm 3.4(3)$ \\
$\begin{array}{l}\text { No. of sperm } \\
\left(\mathrm{x}=10^{6}\right)\end{array}$ & Transgenic mice & $5.2 \pm 0.6(3)$ & $4.5 \pm 0.3^{*}(4)$ & $1.2 \pm 0.8^{*}(5)$ \\
& Wild-type mice & $61 \pm 4.6(3)$ & $45 \pm 6.3(3)$ & $33.6 \pm 6.4(3)$ \\
$\begin{array}{l}\text { Sperm motility (\%) } \\
\text { Transgenic mice }\end{array}$ & $48 \pm 8.2(3)$ & $30.3 \pm 7.0(4)$ & $13.6 \pm 7.4 *(5)$ \\
& Wild-type mice & $42.9 \pm 4.6(3)$ & $27.3 \pm 8.3(3)$ & $21 \pm 4.6(3)$ \\
& Transgenic mice & $29.7 \pm 3.6(3)$ & $19.2 \pm 5.8(4)$ & $6.2 \pm 6.1 *(5)$ \\
\hline
\end{tabular}

Data are the mean \pm SD of the number of individual measurements indicated in parentheses.

* The value for this parameter for transgenic mice is significant different compared with nontransgenic at same ages ( $p<0.001$, Student's $t$ test). 
A
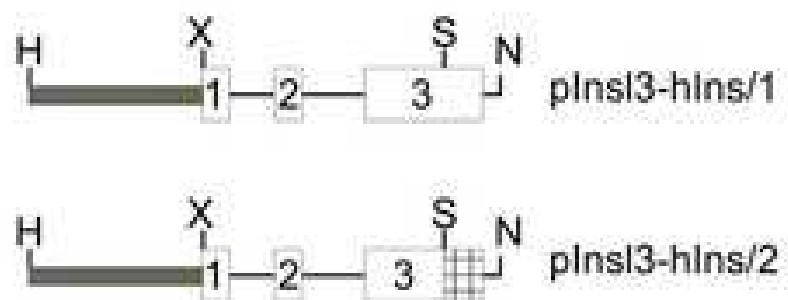

B

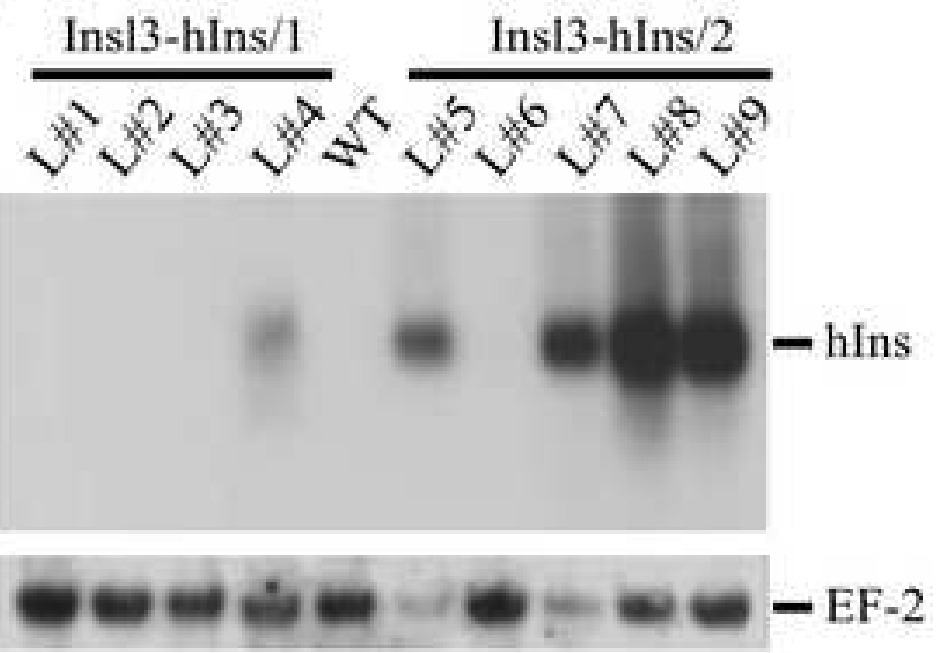

C

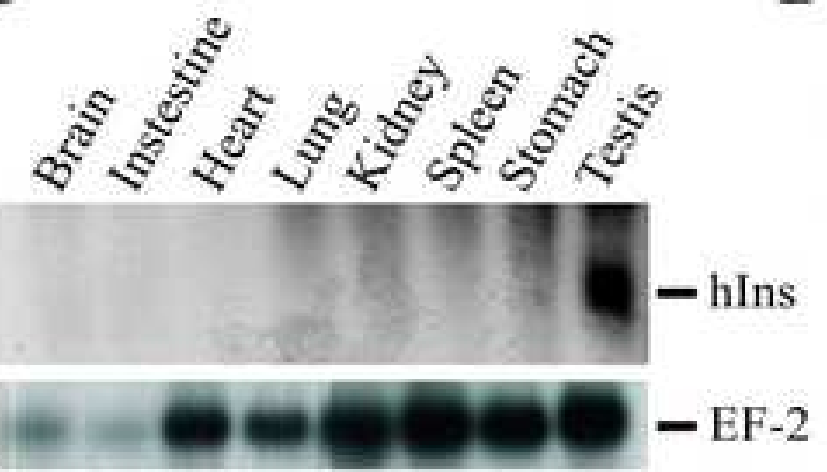

E

D
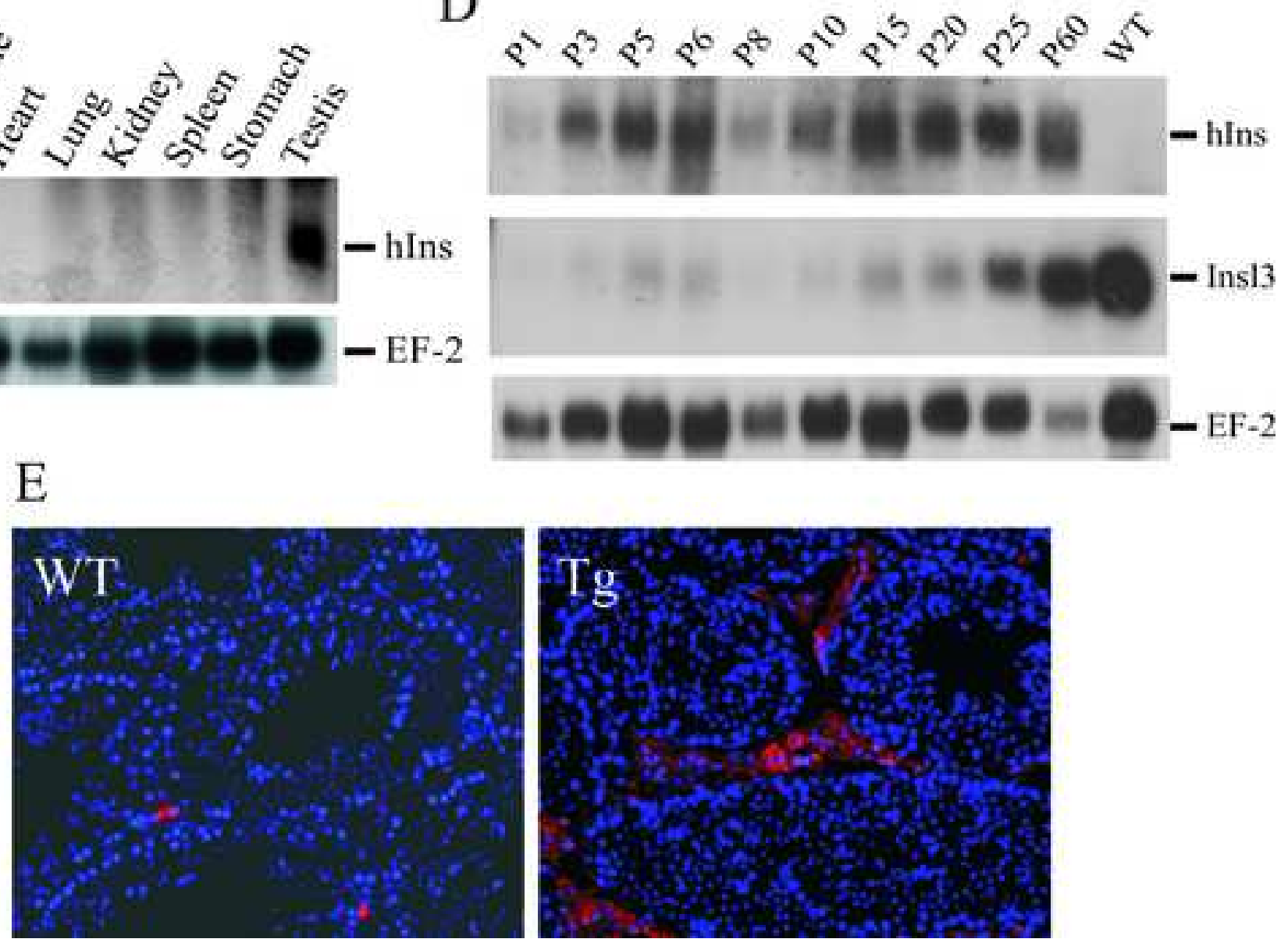
A

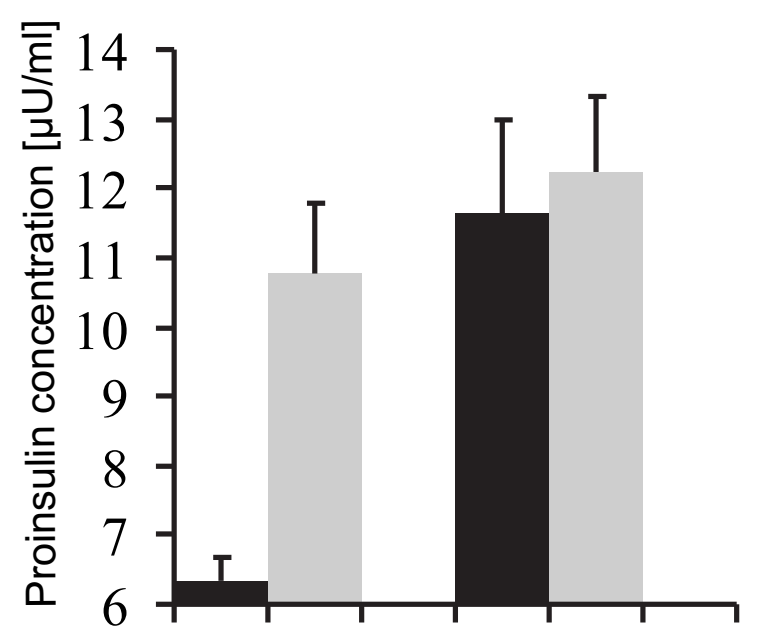

$\frac{\text { WT Tg }}{\text { Testis }} \quad \frac{\text { WT Tg }}{\text { Pancreas }}$

C

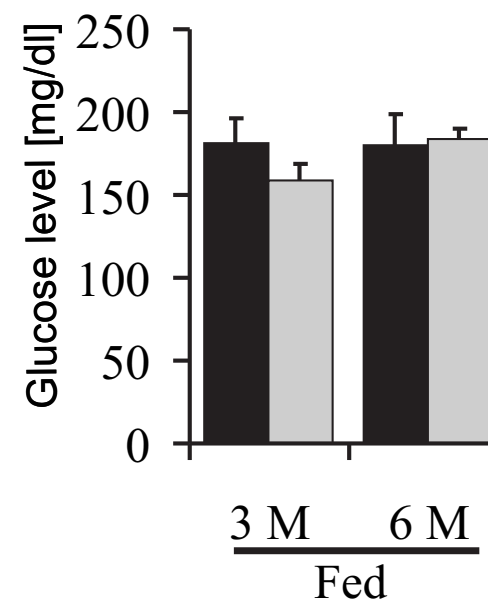

E

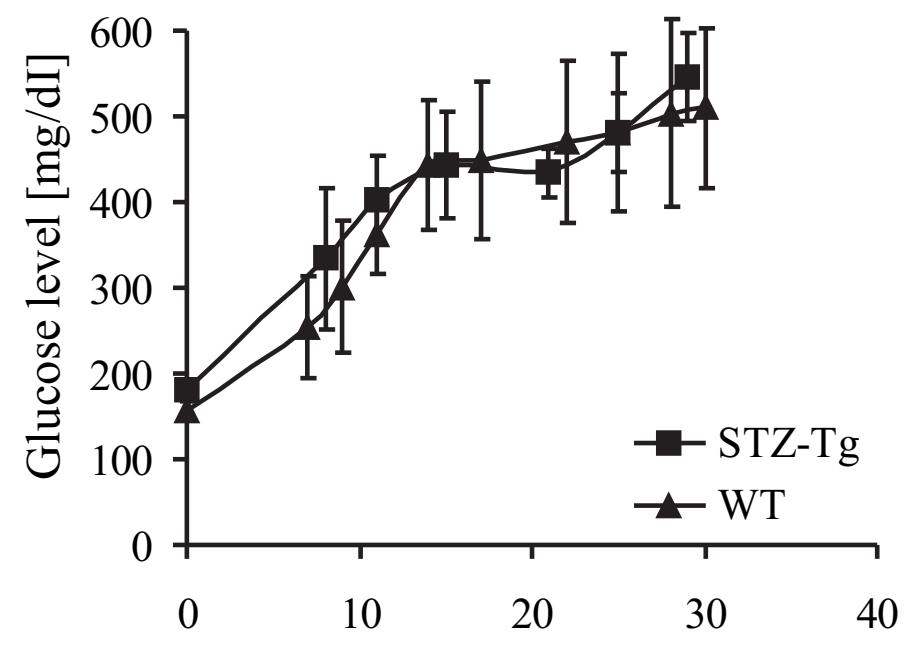

Days after STZ-treatment
B

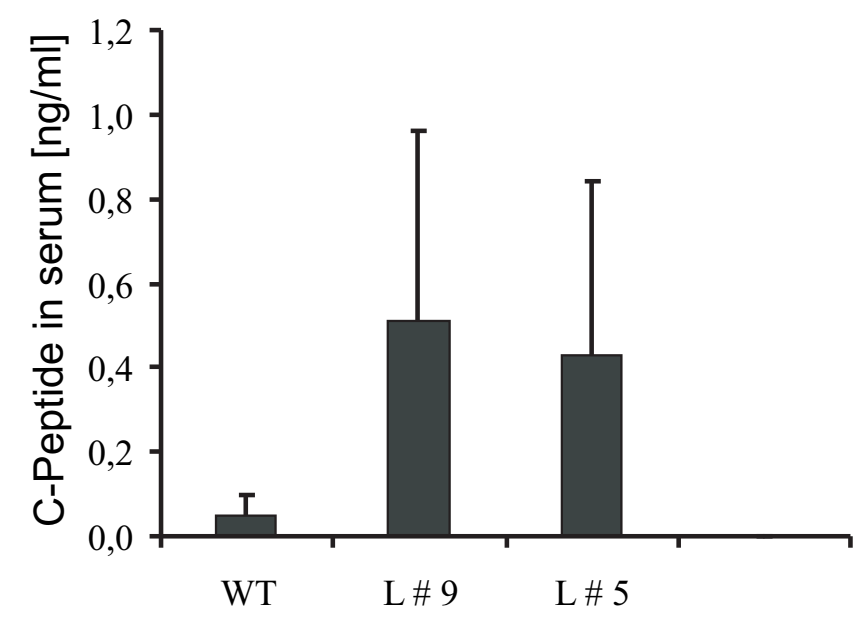

D

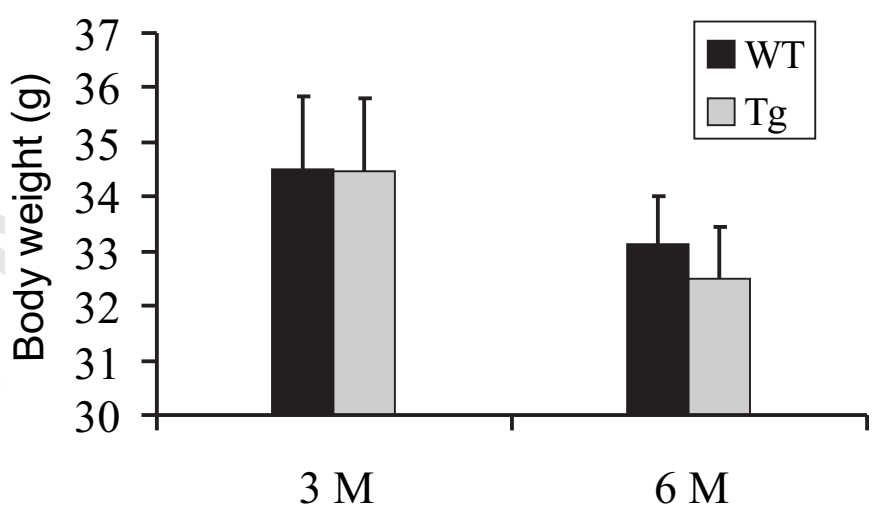

F

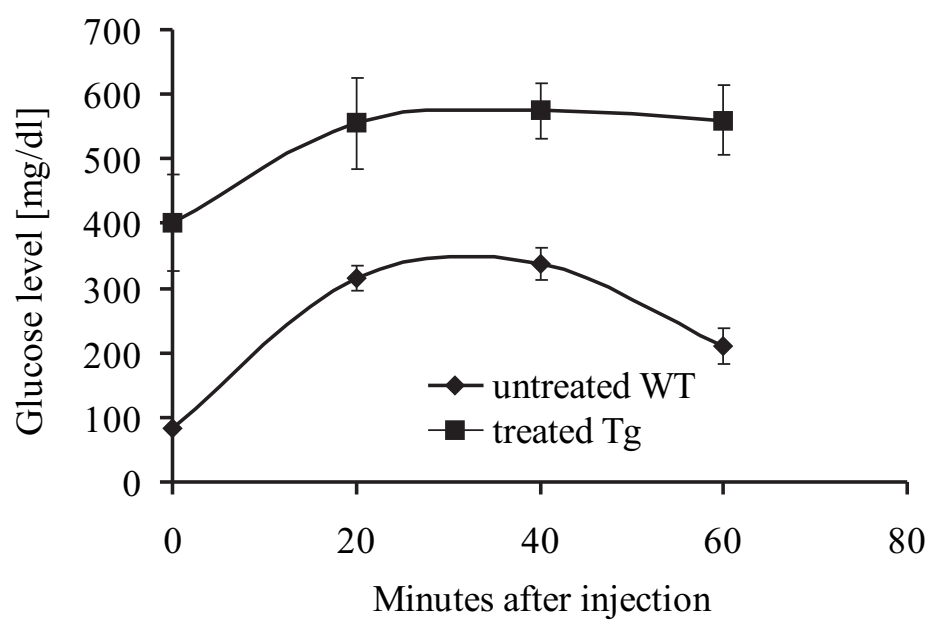



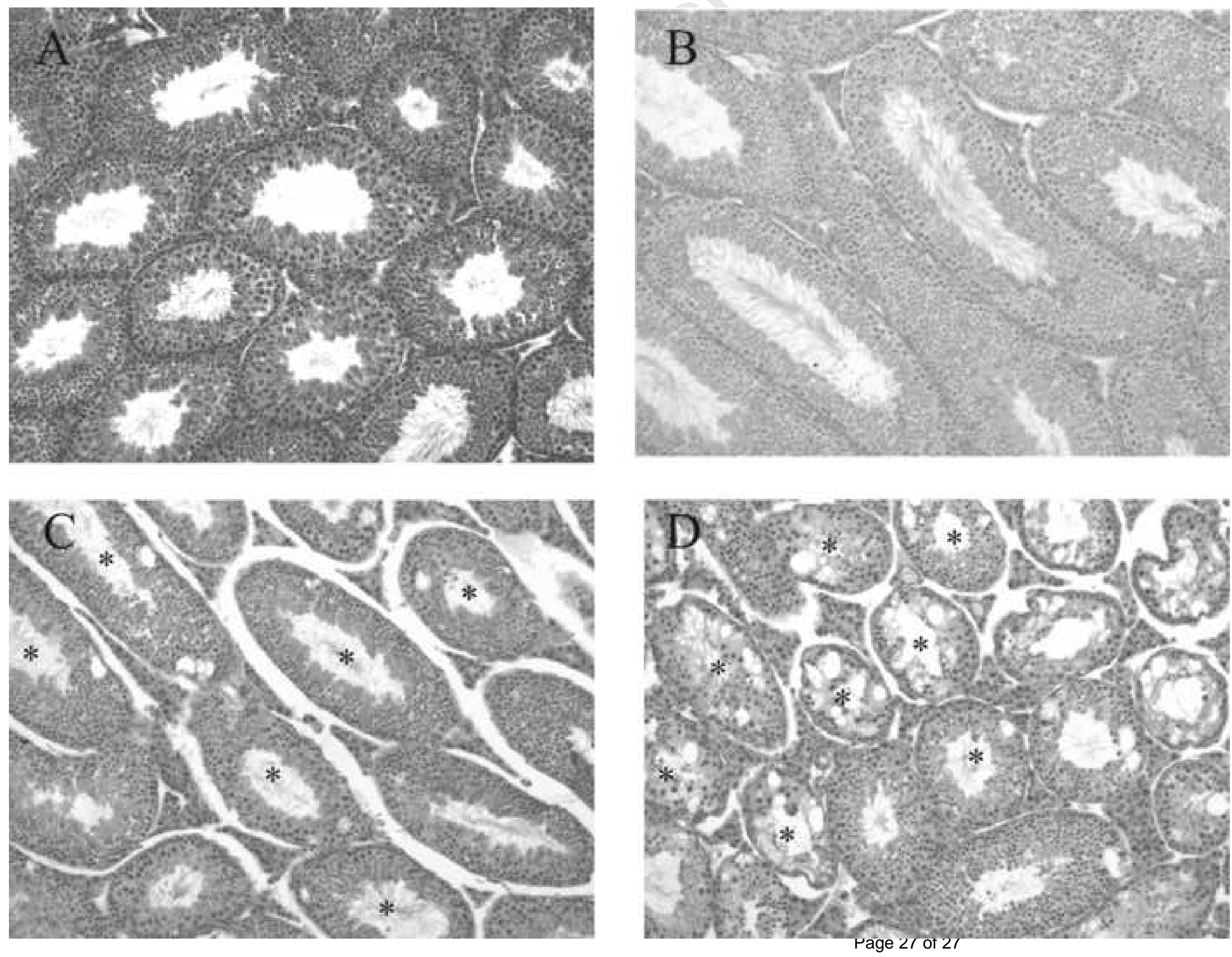